\title{
HUBUNGAN EFIKASI DIRI TERHADAP KEMAMPUAN BERPIKIR TINGKAT TINGGI SISWA SMK PROGRAM KEAHLIAN TEKNIK BANGUNAN PADA MATA PELAJARAN MEKANIKA TEKNIK
}

\author{
Martin Daniel Basito, Riyan Arthur ${ }^{2}$, Daryati ${ }^{3}$ \\ ${ }^{1}$ Alumni PTB FT UNJ, martin1ptbsipil@gmail.com \\ ${ }^{2}$ Dosen PTB FT UNJ, arthur@uni.ac.id \\ 30osen PTB FT UNJ, daryatiss@@unj.ac.id
}

\begin{abstract}
Abstrak
Penelitian ini bertujuan untuk mengetahui hubungan efikasi diri terhadap kemampuan berpikir tingkat tinggi siswa sekolah menengah kejuruan program keahlian teknik bangunan. Permasalahan yang dibahas dalam penelitian ini adalah apakah ada hubungan antara efikasi diri terhadap kemampuan berpikir tingkat tinggi siswa Sekolah Menengah Kejuruan (SMK), dalam hal ini program keahlian teknik bangunan.

Tempat penelitian yang dilakukan di SMK Negeri 4, SMK Negeri 26, SMK Negeri 56 Jakarta ini melibatkan 90 siswa kelas XI program keahlian Teknik Bangunan yang terdiri dari 3 kelas yaitu: kelas XI TKBB SMK Negeri 4, XI TGB SMK Negeri 26, XI TGB SMK Negeri 56 dengan sampel penelitian berjumlah 30 siswa. Metode yang digunakan dalam penelitian ini adalah metode survey dengan pendekatan kuantitatif. Teknik analisis data yang digunakan adalah teknik analisis regresi dan analisis korelasi.

Hasil penelitian menunjukan bahwa : Terdapat hubungan antara efikasi diri terhadap kemampuan berpikir tingkat tinggi siswa yang dibuktikan dengan nilai $t_{\text {hitung }}$ lebih besar dari $t_{\text {tabel }}$ sebesar 2,395 > 1,671 dan signifikansi koefisien korelasi sebesar 0,300, dalam artian memiliki kontribusi tergolong rendah.
\end{abstract}

Kata kunci : Efikasi Diri, Kemampuan Berpikir Tingkat Tinggi.

\section{EFFICIENCY RELATIONSHIPS TO ABILITY HIGH LEVEL ABILITY STUDENTS SMK PROGRAM EXPERTISE BUILDING TECHNIQUES IN MECHANICAL ENGINEERING LESSON TECHNIQUES}

\author{
Martin Daniel Basito, Riyan Arthur ${ }^{2}$, Daryati ${ }^{3}$ \\ ${ }^{1}$ Alumni PTB FT UNJ, martin1ptbsipil@gmail.com \\ ${ }^{2}$ Lecturer of PTB FT UNJ, arthur@,unj.ac.id \\ ${ }^{3}$ Lecturer of PTB FT UNJ, daryatisr@unj.ac.id
}

\begin{abstract}
The objective of this research is to determine the relationship of self efficacy to the ability to think high-level vocational school students vocational building engineering skills program. The problem discussed in this research is the relationship between self efficacy to high-order thinking ability of Vocational High School students, in this case the technique of building technique.

The place of research conducted at SMK Negeri 4, SMK Negeri 26, SMK Negeri 56 Jakarta is involving 90 students of class XI Building Engineering skill program consisting of 3 classes: class XI TKBB SMK Negeri 4, XI TGB SMK Negeri 26, XI TGB SMK Negeri 56 with a sample of research totaling 30 students. The method used in this research is survey method with quantitative approach. Data analysis technique used is technique of regression analysis and correlation analysis.
\end{abstract}


The results showed that: There is a relationship between self efficacy of students' bigh thinking ability as evidenced by the value of tcount greater than ttable of 2.395> 1.671 and significance of correlation coefficient of 0.300 , which means having a relatively low contribution.

Keywords : Self Efficacy, Higher-Order Thinking Skill.

\section{Pendahuluan}

Pendidikan merupakan hal utama bagi kesuksesan masa depan bangsa. Setiap negara di seluruh dunia begitu menekankan pentingnya kualitas pendidikan. Indonesia merupakan salah satu negara yang mengutamakan faktor pendidikan bagi generasi penerus. Seiring berkembangnya zaman, dalam kutipan artikel yang diambil dalam internet pada tanggal 13 November 2017 menjelaskan dengan terbentuknya kawasan ekonomi terintegrasi di wilayah Asia Tenggara yang dikenal dengan istilah Masyarakat Ekonomi ASEAN (MEA) atau ASEAN Economic Community (AEC), Indonesia dan sembilan negara lainnya memasuki persaingan yang sangat ketat. Secara tidak langsung semua orang mempunyai kesempatan untuk bersaing, lebih tepatnya bagi mereka yang mempunyai kompetensi yang baik dalam bidangnya masing-masing.

Sekolah Menengah Kejuruan (SMK) merupakan salah satu satuan pendidikan yang selalu mencetak peserta-peserta didik yang berkualitas untuk menuju ke dunia kerja. Dunia kerja memerlukan kualitas tinggi dan kemampuan yang baik dalam bekerja sama, berfikir, dan berkomunikasi. Untuk terwujudnya harapan tersebut, tentu dibutuhkan kualitas manusia yang baik, yang dapat berfikir dari hal-hal yang sederhana sampai kepada hal-hal yang rumit atau kompleks. Hal tersebut secara tidak langsung menuntut siswa untuk memiliki kecakapan dalam berkomunikasi, berfikir kritis dan kreatif, serta memiliki keterampilan interpersonal yang baik. Seperti yang kita ketahui, kemampuan dalam berfikir kritis dan kreatif merupakan golongan dalam kemampuan berfikir tingkat tinggi pada ranah kognitif bloom, artinya dalam proses pembelajaran yang mendidik siswa untuk menjadi peserta didik yang berkualitas di dunia kerja nantinya dan seiring persaingan global Masyarakat Ekonomi ASEAN (MEA) yang semakin ketat, siswa dituntut untuk tidak lagi berkecimpung hanya pada area kemampuan berfikir tingkat rendah saja, tetapi harus mulai masuk kepada kemampuankemampuan berfikir tingkat tinggi, sehingga benar-benar mencetak lulusan yang mampu berfikir kritis dan kreatif serta bersaing menghadapi persaingan global. Sementara itu, untuk terwujudnya keterampilan interpersonal yang baik perlu adanya penyadaran akan kepercayaan diri peserta didik itu sendiri terhadap kemampuankemampuan yang dimiliki agar tetap memiliki optimisme yang tinggi dalam persaingan global yang sedang dihadapi.

Namun faktanya, pada pencapaian kemampuan berpikir tingkat tinggi siswa yang dibuktikan pada hasil belajar pada mata pelajaran mekanika teknik siswa SMK Negeri 4 kompetensi keahlian Teknik Konstruksi Batu Beton semester 1 tahun ajaran 2016/2017 yang menempati nilai rata-rata 60, siswa SMK Negeri 26 kompetensi keahlian Teknik Gambar Bangunan pada mata pelajaran mekanika teknik semester 1 tahun ajaran 2016/2017 menempati nilai rata-rata 65 , dan SMK Negeri 56 kompetensi keahlian Teknik Gambar Bangunan pada mata pelajaran mekanika teknik semester 1 tahun ajaran 2016/2017 yang juga menepati nilai ratarata 65 pada nilai ujian, yang terlampir pada lampiran halaman 84, dimana persentasi siswa yang memenuhi standar kelulusan hanya $48 \%$ dan $52 \%$ lagi berada dibawah standar kelulusan, secara tidak langsung 
membuktikan masih rendahnya kemampuan berfikir tingkat tinggi siswa. Pembelajaran yang membiasakan siswa untuk berfikir tingkat tinggi adalah salah satu solusi untuk meningkatkan tingkat kemampuan berfikir siswa dengan cara membawa siswa untuk berpikir, mencari sebab apa yang terjadi, mengamati, mencari solusi apa yang harus dilakukan serta pemecahan masalahmasalah dari kejadian atau peristiwa yang dihadapi di kelas. Berdasarkan perbandingan hasil pembelajaran siswa pada mata pelajaran mekanika teknik dengan mata pelajaran lainnya, yakni pada mata pelajaran Gambar Teknik Bangunan siswa SMK Negeri 26 semester 1 tahun ajaran 2016/2017 yang menunjukkan hasil pembelajaran lebih baik, membawa peneliti untuk meneliti apa yang menjadi faktor kegagalan dalam pembelajan mata pelajaran mekanika teknik. Oleh karena itu mata pelajaran yang menjadi keterkaitan dalam penelitian ini ialah mekanika teknik.

Pelajaran mekanika teknik merupakan salah satu mata pelajaran wajib dikuasai seluruh siswa SMK program keahlian teknik bangunan yang ada. Pembelajaran mekanika teknik yang membawa siswa untuk memahami tentang struktur, muatan, sistem gaya, menghitung gaya luar (reaksi perletakan) dari berbagai struktur statis tertentu, menghitung gayagaya dalam (momen, lintang dan normal) dari berbagai truktur statis tertentu, menggambar diagram gaya-gaya dalam, melakukan analisa pada struktur balok menerus, portal bidang, dan rangka batang (Murtinugraha, 2009: 18), yang membawa siswa untuk memahami, menganalisis, dan pemecahan masalah-masalah dalam pembelajaran, jelas merupakan salah satu mata pelajaran yang tepat untuk menunjang tingkat kemampuan berpikir siswa. Myers (2007: 23) mengungkapkan siswa tidak mampu berpikir kritis kecuali mereka dapat mengubah interpretasi mereka dari kenyataan sebenarnya. Ia juga mengungkapkan motivasi dan minat sebagai faktor penting yang mempengaruhi kemampuan berfikir kritis siswa. Hal selaras juga diungkapkan Hoffman (2009: 4), perkembangan kemampuan berfikir dipengaruhi oleh faktor kepribadian, salah satu faktor tersebut berupa efikasi-diri. Menurut Bandura (1997: 12) efikasi-diri menentukan bagaimana seseorang berfikir, berprilaku, dan memotivasi dirinya sendiri. Efikasi diri merupakan salah satu aspek pengetahuan tentang diri yang berpengaruh dalam kehidupan manusia.

Berkesinambungan dengan penelitian yang dilakukan oleh Setiyanto (2014) yang berjudul "Hubungan Antara Efikasi-Diri Dengan Kematangan Karir Siswa Kelas XI SMK Negeri 8 Jakarta" yang menyimpulkan bahwa efikasi diri siswa sangat menentukan tingkat kematangan karir siswa, dimana siswa yang mempunyai efikasi diri yang kuat akan mampu bertahan dalam situasi sulit dan sangat menyukai tugas-tugas yang menantang, sebaliknya siswa yang memiliki efikasi diri rendah cenderung lebih cepat menyerah. Penelitian yang dilakukan Tanta (2013) yang berjudul "Pengaruh Efikasi Diri, Kemandirian Belajar Dan Kebiasaan Berpikir Terhadap Hasil Belajar Biologi SMA Di Kota Jayapura Papua" menunjukkan bahwa ada hubungan yang sangat signifikan antara efikasi diri dan kemandirian dalam belajar. Ada hubungan positif yang signifikan antara efikasi diri dengan kebiasaan berpikir terhadap hasil belajar biologinya, dimana variabel tersebut saling berhubungan.

Berdasarkan data hasil pembelajaran siswa SMK Negeri 4, SMK Negeri 26, dan SMK Negeri 56 yang menempati nilai ratarata 65 pada mata pelajaran mekanika teknik dibanding dengan mata pelajaran yang lain dan pernyataan yang diungkapkan bahwa efikasi diri merupakan salah satu faktor keberhasilan dalam pembelajaran serta hasil penelitian yang telah dijabarkan, peneliti tertarik apakah terdapat hubungan yang signifikan antara efikasi diri siswa dengan kemampuan berfikir tingkat tinggi yang dimilikinya. 
Oleh karena itu, berdasarkan uraian latar belakang tersebut, penelitian ini akan membahas tentang "Hubungan Efikasi Diri Terhadap Kemampuan Berfikir Tingkat Tinggi Siswa SMK Program Keahlian Teknik Bangunan Pada Mata Pelajaran Mekanika Teknik".

\section{Identifikasi Masalah}

Berdasarkan latar belakang masalah yang sudah diuraikan di atas, dapat diidentifikasikan masalahnya sebagai berikut

1. Bagaimanakah efikasi diri (kepercayaan atas kemampuan yang dimiliki dalam mengerjakan suatu hal) siswa SMK program keahlian teknik bangunan pada mata pelajaran mekanika teknik?

2. Apakah seluruh siswa SMK paket keahlian teknik bangunan mempunyai kemampuan berpikir tingkat tinggi pada mata pelajaran mekanika teknik?

3. Apakah efikasi diri (kepercayaan atas kemampuan yang dimiliki dalam mengerjakan suatu hal) merupakan salah satu faktor yang mempengaruhi kemampuan berpikir tingkat tinggi siswa SMK program keahlian teknik Bangunan pada mata pelajaran mekanika teknik?

4. Apakah ada hubungan antara efikasi diri (kepercayaan atas kemampuan yang dimiliki) terhadap kemampuan berfikir tingkat tinggi siswa SMK program keahlian teknik bangunan pada mata pelajaran mekanika teknik?

5. Seberapa besar hubungan yang dimiliki antara efikasi diri dengan kemampuan berpikir tingkat tinggi siswa SMK program keahlian teknik Bangunan pada mata pelajaran mekanika teknik?

\section{Pembatasan Masalah}

Berdasarkan identifikasi masalah, maka batasan masalah yang akan diteliti dibatasi sebagai berikut:

1. Penelitan ini hanya meliputi 3 Sekolah Mengengah Kejuruan (SMK) program keahlian teknik bangunan yakni, SMK Negeri 4, SMK Negeri 26, dan SMK Negeri 56.

2. Penelitian ini hanya ditujukan untuk mata pelajaran mekanika teknik, yang dimana terdapat hasil pembelajaran rata-rata dibawah standar kelulusan.

3. Penelitian ini hanya meneneliti efikasi diri sebagi faktor yang mempengaruhi kemampuan berpikir tingkat tinggi siswa dimana masih banyak faktorfaktor lain yang mempengaruhi.

4. Penelitian ini tidak meliputi kemampuan berpikir tingkat rendah yakni $\mathrm{C}_{1}$ dan $\mathrm{C}_{2}$.

5. Standar kompetensi yang digunakan untuk meneliti variable $\mathrm{Y}$ hanya meliputi Standar Kompetensi 3.1, 3.3, dan 3.5, yang terdapat pada lampiran silabus.

\section{Rumusan Masalah}

Berdasarkan pembatasan masalah di atas, maka permasalahan dalam penelitian ini dapat dirumuskan sebagai berikut :Apakah ada hubungan antara efikasi diri terhadap kemampuan berpikir tingkat tinggi siswa SMK program keahlian teknik bangunan pada mata pelajaran mekanika teknik?

\section{Tinjauan Pustaka}

\section{Efikasi Diri}

Menurut Bandura (1997: 2) efikasi diri adalah keyakinan individu mengenai kemampuannya dirinya dalam melakukan tugas atau tindakan yang diperlukan untuk mencapai hasil tertentu. Sementara itu, Baron dan Byrne (1991: 5) mendefinisikan efikasi diri sebagai evaluasi seseorang 
mengenai kemampuan atau kompetensi dirinya untuk melakukan suatu tugas, mencapai tujuan, dan mengatasi hambatan. Berdasarkan pengertian tersebut, dapat dipahami bahwa efikasi diri meliputi keyakinan yang dimiliki indivudu terhadap kemampuan yang dimilikinya dan evaluasi seseorang terhadap kemampuan dan kompetensi dirinya untuk melakukan suatu tugas untuk mencapai hasil tertentu. Hal yang selaras juga diungkapkan oleh Luthans (2006: 102) seperti dibawah ini:

\section{"Efikasi diri mengacu pada} keyakinan individu (atau konfidensi) mengenai kemampuannya untuk memobilisasi motivasi, sumber daya kognitif, dan tindakan yang diperlukan agar berhasil melaksanakan tugas dalam konteks tertentu."

\section{Berdasarkan definisi yang} dijabarkan, ditarik kesimpulan bahwa efikasi diri mengacu pada tingkat keyakinan atau konfidensi seseorang terhadap kemampuan yang dimilikinya, yang secara tidak langsung akan memotivasi dirinya sendiri untuk melakukan tindakan yang diperlukan untuk mencapai suatu hal tertentu. Penjabaran yang lebih luas lagi dikemukakan oleh Bandura (1997:3) dan Luthans (2006: 103), seperti dibawah ini:

"efikasi diri mengacu pada keyakinan akan kemampuan individu untuk menggerakkan motivasi, kemampuan kognitif, dan tindakan yang diperlukan untuk memenuhi tuntutan situasi. Efikasi diri tidak berkaitan dengan kecakapan yang dimiliki, tetapi berkaitan dengan keyakinan individu mengenai hal yang dapat dilakukan dengan kecakapan yang ia miliki seberapapun besarnya".

Luthans (2006: 103) mengatakan bahwa efikasi diri dapat membawa pada prilaku yang berbeda diantara individu dengan kemampuan yang sama karena efikasi diri mempengaruhi pilihan, tujuan, pengatasan masalah, dan kegigihan dalam berusaha. Seseorang dengan efikasi diri yang tinggi, percaya bahwa mereka mampu melakukan sesuatu untuk mengubah kejadian-kejadian di sekitarnya, sedangkan seseorang dengan efikasi diri rendah menganggap dirinya pada dasarnya tidak mampu mengerjakan segala sesuatu yang ada disekitarnya. Dalam situasi yang sulit, orang dengan efikasi diri yang rendah cenderung akan mudah menyerah. Sementara orang dengan efikasi diri yang tinggi akan berusaha lebih keras untuk mengatasi tantangan yang ada. Dapat disimpulkan bahwa efikasi diri akan mempengaruhi bebrapa aspek dari kognisi dan perilaku seseorang, oleh karena itu perilaku suatu individu akan berbeda dengan individu yang lain.

Berdasarkan pengertian-pengertian yang telah dijabarkan, dapat dipahami bahwa efikasi diri adalah kepercayaan seseorang terhadap kemampuan yang dimilikinya terhadap apa yang sedang dihadapi, yakni meyakinkan diri untuk memaksimalkan pencapaian tertentu dengan memotivasi diri, memaksimalkan sumber daya kognitif yang dimiliki, dan tindakan yang diperlukan dalam menangani hambatan atau pencapaian tertentu. Orang yang mempunyai efikasi diri yang tinggi cenderung memiliki paradigma yang positif akan kemampuan dirinya sendiri dan mampu melakukan sesuatu untuk mengubah keadaan disekitarnya, sebaliknya orang yang memiliki efikasi diri yang rendah cenderung mengangap dirinya tidak mampu menyelesaikan sesuatu dan mudah menyerah serta memiliki paradigma negatif akan kemampuan yang dimiliki.

Menurut Luthan (2006: 103) efikasi diri dapat dipahami dan didapat informasinya melalui empat (4) sumber informasi utama, yakni:

1) Pengalaman keberhasilan (Mastery Experience)

Pengalaman keberhasilan memberikan pengaruh besar pada efikasi diri individu karena didasarkan pada pengalaman-pengalaman pribadi individu 
secara nyata yang berupa keberhasilan dan kegagalan. Pengalaman keberhasilan akan menaikan efikasi diri individu, sedangkan pengalaman kegagalan akan menurunkannya.

2) Pengalaman orang lain (Vicarious Experience)

Pengamatan terhadap keberhasilan orang lain dengan kemampuan yang sebanding dalam mengerjakan suatu tugas akan meningkatkan efikasi diri individu dalam mengerjakan tugas yang sama. Begitu pula sebaliknya, pengamatan terhadap kegagalan orang lain akan menurunkan penilaian individu mengenai kemampuannya dan individu akan mengurangi usaha yang dilakukan.

3) Persuasi Verbal (Verbal Persuasion)

Pada persuasi verbal, individu diarahkan dengan saran, nasihat, dan bimbingan sehingga dapat meningkatkan keyakinannya tentang kemampuankemampuan yang dimiliki yang dapat membantu mencapai tujuan yang diinginkan. Individu yang diyakinkan secara verbal cenderung akan berusaha lebih keras untuk mencapai suatu keberhasilan. Pengaruh persuasi verbal tidaklah terlalu besar karena tidak memberikan suatu pengalaman yang dapat langsung dialami atau diamati individu.

4) Kondisi Fisiologis (Physiological State) Individu akan mendasarkan informasi mengenai kondisi fisiologis mereka untuk menilai kemampuannya. Ketegangan fisik dalam situasi yang menekan dipandang individu sebagai suatu tanda ketidakmampuan karena hal itu dapat melemahkan performansi kerja individu.

Berdasarkan penjabaran sumbersumber informasi efikasi diri yang diungkapkan oleh Luthans F (2006: 103), dapat dipahami bahwa efikasi diri setiap individu dapat dipahami melalui empat (4) sumber yakni:

(1) Pengalaman keberhasilan (Mastery Experience), dimana sumber informasi seseorang dapat dipahami melalui pengalaman keberhasilan maupun pemgalaman kegagalan yang dimiliki suatu individu. Artinya pengalaman induvidu tersebut akan sangat mempengaruhi efikasi dirinya sendiri.

(2) Pengalaman orang lain (Vicarious Experience), dimana hampir memiliki artian yang sama dengan Mastery Experience namun, dalam hal ini yang menjadi sumber informasi efikasi diri seseorang didapat melalui pengalaman keberhasilan maupun kegagalan orang lain yang kemungkinan memiliki tingkat kesulitan yang sama dengan yang sedang dihadapi, sehingga secara tidak langsung juga dapat mempengaruhi efikasi diri individu tersebut.

(3) Persuasi verbal (Verbal Persuasion), dimana efikasi diri seseorang dapat meningkat atau sebaliknya berdasarkan dukungan atau faktor eksternal yang diberikan seperti motivasi, saran, nasihat, dan bimbingan yang didapat induvidu tersebut.

(4) Kondisi fisiologis (Physiological State), dimana efikasi seseorang juga dipengaruhi oleh faktor kondisi fisiologi induvidu,. Kondisi fisiologis yang baik akan meningkatkan efikasi diri induvidu tersebut, sebaliknya kondisi fisiologis yang tidak baik akan menurunkan efikasi dirinya.

Menurut Luthans (2006: 104) efikasi diri pada diri tiap individu akan berbeda antara satu individu dengan yang lainnya berdasarkan tiga dimensi. Berikut ini adalah tiga dimensi tersebut:

1) Dimensi Tingkat/Besaran (Magnitude)

Dimensi ini berkaitan dengan derajat kesulitan tugas ketika individu merasa mampu untuk melakukannya. Apabila individu dihadapkan pada tugastugas yang disusun menurut tingkat kesulitannya, maka efikasi diri individu mungkin akan terbatas pada tugas-tugas yang mudah, sedang, atau bahkan meliputi tugas-tugas yang paling sulit, sesuai dengan batas kemampuan yang dirasakan untuk memenuhi tuntutan perilaku yang dibutuhkan pada masing-masing tingkat. Individu akan mencoba tingkah laku yang berada di luar batas kemampuan yang dirasakannya. 
2) Dimensi Luas Bidang (Generalilty)

Dimensi ini berkaitan dengan luas bidang tingkah laku yang mana individu merasa yakin akan kemampuannya. Individu dapat merasa yakin terhadap kemampuan dirinya. Apakah terbatas pada suatu aktivitas dan situasi tertentu atau pada serangkaian aktivitas dan situasi yang bervariasi.

\section{3) Dimensi Kekuatan (Strenght)}

Dimensi ini berkaitan dengan tingkat kekuatan dari keyakinan atau pengharapan individu mengenai kemampuannya. Pengharapan yang lemah mudah digoyahkan oleh pengalamanpengalaman yang tidak mendukung. Sebaliknya, pengalaman-pengalaman yang mantap mendorong individu tetap bertahan dalam usahanya. Dimensi ini biasanya berkaitan langsung dengan dimensi level, yaitu makin tinggi taraf kesulitan tugas, makin lemah keyakinan yang dirasakan untuk menyelesaikannya.

Berdasarkan dimensi-dimensi efikasi diri yang diungkapkan, maka dapat dipahami bahwa efikasi diri tiap individu akan berbeda satu dengan yang lainnya berdasarkan tiga (3) dimensi, yakni:

Dimensi

Tingkat/Besaran (Magnitude), pada dimensi ini efikasi diri seseorang diukur berdasarkan tingkat kesulitan tugas yang di terima individu tersebut, dimana seseorang yang memiliki efikasi diri yang rendah cenderung menyerah pada tugas-tugas yang mudah atau sedang, sedangkan seseorang yang memiliki efikasi diri yang tinggi akan terus berusaha sampai pada tugas-tugas yang sulit, bahkan diluar kemampuan yang dimiliki.

Dimensi Luas Bidang (Generality), dimensi ini mengukur efikasi diri seseorang berdasarkan keterbatasan kemampuan yang dimiliki individu dalam bidang atau kondisikondisi tertentu saja. Orang yang efikasi dirinya rendah akan merasa nyaman dalam bidang-bidang atau situasi tertentu saja, sebaliknya seseorang yang memiliki efikasi diri yang tinggi akan mencoba dan memaksimalkan kemampuannya bahkan dalam bidang atau kondisi-kondisi diluar kemampuannya. Dimensi Kekuatan (Strenght), pada dimensi ini efikasi diri seseorang diukur berdasarkan tingkat kekuatan dari keyakinan yang dimiliki individu. Seseorang yang memiliki efikasi diri yang tinggi akan memiliki keyakinan yang tinggi akan kemampuan dirinya, sebaliknya seseorang yang memiliki efikasi diri yang rendah cenderung tidak yakin dan menyerah akan kemampuan yang dimiliki.

\section{Kemampua Berpikir Tingkat Tinggi}

Kemampuan berfikir tingkat tinggi atau disebut juga dengan HOTS (High Order Thingking Skills), merupakan urutan tingkat berfikir dalam pengklasifikasian taksonomi Bloom. Pada taksonomi Bloom, HOTS merupakan tingkat kemampuan berfikir pada level menerapkan, menganalisis, mengevaluasi, dan mencipta secara kognitif. Menurut Brookhart (2010: 3) definisi dari HOTS (High Order Thingking Skils) terdiri dari tiga kategori: (1) mendefinisikan kemampuan berfikir tingkat tinggi dalam hal transfer, (2) mendefinisikan kemampuan berfikir tingkat tinggi dalam hal berfikir kritis, (3) dan mendefinisikan kemampuan berfikir tingkat tinggi dalam hal pemecahan masalah. Berikut adalah definisi kemampuan berfikir tingkat tinggi dalam hal transfer menurut Anderson (2001:23) diacu dalam (Brookhart (2010: 3):

"Dua hal yang paling penting dalam tercapainya keberhasilan dalam pendidikan ialah untuk memberikan kesempatan pada daya ingat dan untuk memberikan kesempatan mentransfer (apa saja, kapan itu terjadi, menampilkan pemahaman pembelajaran), memberikan kesempatan siswa menunjukkan apa yang mereka telah pelajari, dimana mentranser tidak hanya memaksa siswa untuk mengingat, tetapi juga untuk memaksa siswa memahami serta dapat menggunakan apa yang telah mereka pelajari."

Sedangkan definisi kemampuan berfikir tingkat tinggi dalam hal berfikir kritis 
menurut Norris \& Ennis (1989: 3) diacu dalam Brookhart (2010: 4) menyatakan bahwa pemikiran kritis itu masuk akal, sedangkan pemikiran reflektif itu terfokus pada apa yang harus dipercayai atau dilakukan. Hal yang sama juga diungkapkan oleh Barahal (2008: 299) diacu dalam Brookhart (2010: 4):

“Berfikir kritis ialah "berfikir kreatif”, yang meliputi penalaran, tanya jawab, dan menyelidiki, mengamati dan menggambar, membandingkan dan menghubungkan, menemukan kompleksitas, dan mengeksplorasi sudut pandang."

Di samping itu, definis kemampuan berfikir tingkat tinggi dalam hal pemecahan masalah menurut Nitko \& Brookhart (2007: 215) diacu dalam Brookhart (2010: 4) adalah:

"Seorang siswa mendapatkan masalah ketika siswa ingin mendapatkan hasil yang spesifik tetapi tidak secara otomatis memahami dengan baik bagian atau solusi yang tepat yang digunakan untuk mencapainya. Pemecahan masalah pertama ialah bagaimana mencapai hasil yang diinginkan. Karena siswa tidak bisa secara otomatis memahami dengan baik solusi yang tepat untuk mencapai pemecahan masalah tersebut, secara tidak langsung siswa harus menggunakan satu atau lebih kemampuan berfikir tingkat tinggi. Kemampuan berfikir tersebut disebut pemecahan suatu masalah."

Berdasarkan pengertian-pengertian yang telah dijabarkan dapat dipahami bahwa kemampuan berpikir tingkat tinggi adalah kemampuan dalam berpikir, bertindak, dan berprilaku dalam menghadapi suatu masalah atau tantangan dimana kemampuan yang dimaksud adalah kemampuan dalam tingkat yang kritis dan kompleks yang secara tidak langsung menuntut individu untuk menganalisis dan menemukan sumber permasalahan, menghubungkan solusi atau jalan keluar permasalahan, sampai kepada pemecahan masalah tersebut.

Berdasarkan taksonomi Bloom yang telah direvisi menurut Anderson (2011: 99), tingkat kemampuan kognitif digolongkan dalam enam (6) tingkat, yaitu:

1. Mengingat (Remember), melibatkan penarikan/pengulangan kembali fakta dan konsep.

2. Memahami (Understand), melibatkan pemahaman dasar, dipahami dalam pengertian yang lebih baru yang menekankan siswa membangun makna mereka sendiri. Proses dalam kategori ini meliputi interpretasi, pencerminan, klasifikasi, rangkuman, menyimpulkan, membandingkan, dan menjelaskan.

3. Mengaplikasikan (Apply), melibatkan penggunaan prosedur-prosedur tertentu untuk mengerjakan soal latihan atau menyelesaikan maslah. Proses dalam kategori ini meliputi mengeksekusi dan mengimplementasikan.

4. Menganalisis (Analyze), melibatkan proses memecah-mecah materi jadi bagian-bagian kecil dan menentukan bagaimana hubungan antar-bagian dan antar setiap bagian dan struktur keseluruhannya. Proses dalam kategori ini meliputi membedakan, mengorganisasi, dan mengatribusikan.

5. Mengevaluasi (Evaluate), didefinisikan sebagai membuat keputusan berdasarkan kriteria dan standar. Kriteria-kriteria yang paling sering digunakan adalah kualitas, efektivitas, efisiensi, dan konsistensi kriteriakriteria ini ditentukan oleh siswa.

6. Mencipta (Create), melibatkan proses menyusun elemen-elemen jadi sebuah keseluruhan yang koheren dan fungsional. Tujuan yang diklasifikasikan dalam mencipta meminta siswa membuat produk baru dengan mengorganisasi sejumlah elemen atau bagian jadi suatu pola atau struktur yang tidak pernah ada sebelumnya.

Berdasarkan taksonomi Bloom yang telah dijabarkan, tingkat kemampuan berfikir seseorang digolongkan menjadi dua (2), yakni kemampuan berfikir tingkat rendah (Low Order Thingking Skills), dan 
kemampuan berfikir tingkat tinggi (High Order Tbingking Skills). Pada dasarnya dua aspek pertama yaitu mengingat (Remamber) dan memahami (Understand), merupakan kemampuan berfikir tingkat rendah (LOTS), empat aspek berikutnya yaitu mengaplikasikan (Apply), menganalisi (Analyz), mengevaluasi (Evaluate), dan mencipta (Create) merupakan kemampuan berfikir tingkat tinggi.

Berdasarkan penjelasan sebelumnya dapat dipahami bahwa kemampuan berfikir tingkat tinggi (HOTS) meliputi mengaplikasikan (Apply), menganalisi (Analyz), mengevaluasi (Evaluate), dan mencipta (Create). Oleh karena itu, berikut asesmen masing-masing aspek kemampuan berfikir tingkat tinggi menurut Anderson (2011: 24):

\section{Mengaplikasikan $(A p p l y)$}

Mengaplikasikan melibatkan penggunaan prosedur-prosedur tertentu untuk mengerjakan soal latihan atau menyelesaikan masalah. Kategori mengaplikasikan terdiri dari dua proses kognitif, yakni mengeksekusi ketika tugas yang diberikan hanya berupa soal latihan (yang familier), dan mengimplementasikan ketika tugasyang diberikan berupa masalah yang baru (tidak familier). Dimana mengeksekusi membawa siswa secara rutin menerapkan prosedur ketika menghadapi tugas yang sudah familier. Format asesmennya siswa diberikan tugas yang sudah biasa diselesaikan dan diminta untuk mencari sendiri jawabannya atau memilih dari pilihan jawaban yang disediakan, sedangkan mengimplementasikan berlangsung saat siswa memilih dan menggunakan sebuah prosedur untuk menyelesaikan tugas yang tidak familier. Format asesmennya siswa diberikan masalah yang tidak familier yang harus diselesaikan, dimana siswa diminta mencari prosedur yang dibutuhkan untuk merampungkan masalahnya, atau diminta memilih prosedurnya, atau biasanya mencari sekaligus memilih prosedurnya.

\section{Menganalisi (Analyz)}

Menganalisi mencakup belajar untuk menentukan potongan-potongan informasi yang relevan atau penting (membedakan), menentukan cara-cara untuk menata potongan-potongan informasi tersebut (mengorganisasikan), dan menentukan tujuan dibalik informasi itu (mengatribusikan). Dimana membedakan melibatkan proses memilah-milah bagian-bagian yang relevan atau penting dari sebuah struktur. Format asesmen kemampuan untuk membedakan dapat diases dengan soal-soal jawaban singkat atau pilihan, dimana siswa diberi sebuah kalimat dan diminta untuk menunjukkan bagian-bagian mana yang paling penting atau relevan.

Dalam mengorganisasi siswa membangun hubungan-hubungan yang sistematis dan koheren antar potongan informasi. Mengorganisasi biasanya terjadi bersamaan dengan proses membedakan. Siswa mula-mula mengidentifikasi elemenelemen yang relevan atau penting dan kemudian menentukan sebuah struktur yang terbentuk dari elemen-elemen itu. Format asesmen untuk mengorganisasi dapat berupa jawaban singkat atau soal pilihan. Dalam soal jawaban singkat, siswa diminta menulis garis besar sebuah tulisan. Dalam soal pilihan, diminta memilih salah satu dari empat struktur organisasi yang paling sesuai dengan organisasi yang dipaparkan dalam tulisan.

Sedangkan mengatribusikan terjadi ketika siswa dapat menentukan sudut pandang, pendapat, nilai, atau tujuan di balik komunikasi. Mengatribusikan melibatkan proses dekonstruksi, yang di dalamnya siswa menentukan tujuan pengarang suatu tulisan yang diberikan oleh guru. Format asesmen mengatribusikan dapat diases dengan memberikan materi tulisan atau lisan dan kemudian meminta siswa membuat atau memilih deskripsi tentang sudut pandang, pendapat, dan tujuan penulis atau pembicara. 


\section{Mengevaluasi (Evaluate)}

Kategori mengevaluasi mencakup proses kognitif memeriksa (keputusankeputusan yang diambil berdasarkan kriteria internal) dan mengkritik (keputusankeputusan yang diambil berdasarkan kriteria eksternal). Memeriksa melibatkan proses menguji inkonsistensi atau kesalahan internal dalam suatu operasi atau produk. Misalnya, memeriksa terjadi ketika siswa menguji apakah suatu kesimpulan sesuai dengan premis-premisnya atau tidak, apakah data-datanya mendukung atau menolak hipotesis, atau apakah suatu bahan pelajaran berisikan bagian-bagian yang saling bertentangan.

Format asesmennya. Tugas-tugas memriksa dapat memanfaatkan proses atau produk yang diberikan kepada siswa atau yang diciptakan oleh siswa sendiri. Sedangkan mengkritik melibatkan proses penilaian suatu produk penilaian suatu produk atau proses berdasarkan kriteria dan standar eksternal. Dalam mengkritik, siswa mencatat ciri-ciri positif dan negatif dari suatu produk dan membuat keputusan setidaknya sebagian berdasarkan ciri-ciri tersebut. Mengkritik merupakan inti dari apa yang disebut dengan berpikir kritis. Format asamennya, siswa diminta untuk mengkritik hipotesis atau pendapatnya sendiri atau pendapat orang lain. Kritik dapat didasarkan pada kriteria-kriteria positif, negatif, atau keduannya dan menghasilkan konsekuensi-konsekuensi positif dan negatif.

\section{Mencipta (Create)}

Mencipta melibatkan proses menyusun elemen-elemen jadi sebuah keseluruhan yang koheren atau fungsional. Proses-proses kognitif yang terlibat dalam mencipta umumnya sejalan dengan pengalaman-pengalaman belajar sebelumnya. Tujuan-tujuan yang diklasifikasikan dalam mencipta meminta siswa membuat produk baru dengan mengorganisasi sejumlah elemen atau bagian jadi suatu pola atau struktur yang tidak pernah ada sebelumnya. Tahap mencipta melibatkan merumuskan, merencanakan, dan memproduksi.

Merumuskan melibatkan proses menggambarkan masalah dan membuat pilihan atau hipotesis yang memenuhi kriteria-kriteria tertentu. Ketika merumuskan melampaui batas-batas pengetahuan lama dan teori-teori yang ada, proses kognitif ini melibatkan proses berfikir divergen dan menjadi inti dari apa yang disebut berpikir kreatif. Format asesmennya. Untuk mengases proses kognitif merumuskan, dibutuhkan format asesmen jawaban singkat yang meminta siswa membuat alternatif atau hipotesis. Format jawaban singkat dibedakan jadi tugas konsekuensi (consequenses task) dan tugas manfaat (uses task). Sedangkan merencanakan melibatkan proses merencanakan metode penyelesaian masalah yang sesuai dengan kriteria-kriteria masalahnya yakni membuat rencana untuk menyelesaikan masalah. Merencanakan adalah mempraktikkan langkah-langkah untuk menciptakan solusi yang nyata bagi suatu masalah.

Format asesmennya. Merencanakan dapat diases dengan meminta siswa mencari solusi yang realistis, mendeskripsikan rencanarencana penyelesaian masalah, atau memilih rencana-rencana penyelesaian masalah yang tepat. Oleh karena itu, memproduksi melibatkan proses melaksanakan rencana untuk menyelesaikan masalah yang memenuhi spesifikasi-spesifikasi tertentu. Format asesmennya, tugas yang jamak digunakan untuk mengases kemampuan memproduksi adalah tugas untuk merancang. Disini siswa diminta untuk menciptakan produk sesuai dengan spesifikasi-spesifikasi tertentu.

\section{Metodologi Penelitian}

\section{Tempat dan Waktu Penelitian}

Penelitian ini dilakukan di SMK Negeri 4, SMK Negeri 26, dan SMK Negeri 
56 Jakarta. Penelitian ini dilaksanakan pada bulan November Tahun 2017.

\section{Metode Penelitian}

Dalam penelitian ini penulis menggunakan metode survey dengan desain deskriptif korelasional. Penelitian ini bersifat kuantitatif, dimana gejala-gejala yang akan diteliti diukur dengan menggunakan angka-angka. Dengan demikian penelitian ini memungkinkan digunakan teknik analisis statistik untuk mengolah data.

\section{Hasil Penelitian dan Pembahasan}

Pada tahap pertama, siswa diberikan kuesioner dan soal pilihan ganda (PG) untuk memvalidasi butir soal yang valid untuk mengukur efikasi diri dan kemampuan berpikir tingkat tinggi siswa kepada 30 orang sebagai sampel. Kemudian butir soal dan instrument kuesioner yang valid digunakan untuk penelitian. Kemudian didapat hasil analisis variable $\mathrm{X}$ rata-rata nilai efikasi diri yang dimiliki siswa sebesar $75,95 \%$, dan rata-rata nilai keseluruhan siswa yang memiliki kemampuan berpikir tingkat tinggi sebesar 66,58\%. Disimpulkan bahwa Siswa memiliki efikasi diri yang tinggi namun memiliki kemampuan berpikir yang tergolong cukup. Berdasarkan hasil penelitian juga didapat nilai tertinggi pada variabel efikasi diri siswa sebesar 129 dan nilai terendah 51. Pada variabel kemampuan berpikir tingkat tinggi diperoleh nilai terbesar adalah 95 dan nilai terendah 22,5. Terjadi peningkatan pada rata-rata, nilai minimum, dan nilai maksimum yang diperoleh.

Selanjutnya data diolah menggunakan uji signifikansi koefisien regresi sederhana untuk mengetahui adanya hubungan antara efikasi diri dengan kemampuan berpikir tingkat tinggi siswa SMK program keahlian teknik bangunan pada mata pelajaran mekanika teknik. Berdasarkan perhitungan koefisien regresi diperoleh Fbitung $=2,395$ $>$ Ftabel $=1,671$ pada taraf signifkan 0,05 $(5 \%)$. Dari hasil penelitian juga didapat koefisien korelasi sebesar 0,300, dan koefisien determinasi sebesar 0,900 dimana persamaan regresi yang didapat adalah $Y=17,021+0,093 X$. Dimana berdasarkan persamaan regresi, dapat disimpulkan bahwa bila nilai efikasi diri siswa naik sebesar satu point, maka nilai kemampuan berpikir tingkat tinggi siswa akan naik sebesar 0,093. Dengan ini dapat diketahui terdapat hubungan antara efikasi diri terhadap kemampuan berpikir tingkat tinggi siswa SMK program keahlian teknik bangunan pada mata pelajaran mekanika teknik.

\section{Kesimpulan, Implikasi dan Saran}

\section{Kesimpulan}

Berdasarkan hasil penelitian, dapat ditarik kesimpulan bahwa terdapat hubungan antara efikasi diri terhadap kemampuan berpikir tingkat tinggi yang dimiliki siswa SMK program keahlian teknik bangunan pada mata pelajaran mekanika teknik. Adapun kesimpulan lainnya yang didapat dalam penelitian adalah sebagai berikut:

1. Dalam variable $X$ pada masing-masing dimensi menunjukkan bahwa rata-rata siswa SMK program keahlian teknik bangunan mengerjakan tugas-tugas sekolahnya mulai dari yang sangat mudah, mudah, cukup mudah, sukar, dan sangat sukar untuk membangun semangat belajarnya. Selain itu, hasil penelitian juga menunjukkan bahwa rata-rata siswa memiliki luasan bidang prilaku yang baik dalam menghadapi berbagai macam tugas dan ujian, serta memiliki ketekunan dalam menyelesaikan tugas mekanika teknik yang sulit.

2. Dalam variable $Y$ pada masing-masing dimensi menunjukkan bahwa rata-rata siswa SMK program keahlian teknik bangunan mampu dalam memilih gaya internal struktur dengan benar 100\%, menentukan besarnya resultan gaya, menganalisis konstruksi balok sederhana, membenarkan kesalahan 
hasil perhitungan, dan membangun pemahaman-pemahaman yang baru.

3. Pada variable $\mathrm{X}$ dan $\mathrm{Y}$ terdapat hubungan yang tergolong rendah. Dimana koefisien korelasi sebesar 0,300 dan koefisien determinasi sebesar 0,900 serta persamaan regresi $\mathrm{Y}=17,021+0,093 \mathrm{X}$. Maka dapat disimpulkan bila nilai efikasi diri siswa meningkat 1 point, maka kemampuan berpikir tingkat tinggi siswa akan meningkat pula sebesar 0,300 ..

\section{Implikasi}

Hasil penelitian yang menunjukkan bahwa terdapat hubungan antara efikasi diri terhadap kemampuan berpikir tingkat tinggi siswa SMK program keahlian teknik bangunan pada mata pelajaran mekanika teknik, mengandung implikasi bahwa untuk meningkatkan kemampuan berpikir tingkat tinggi siswa dapat dilakukan dengan lebih meningkatkan tingkat kepercayaan siswa akan kemampuan yang dimilikinya, yakni meningkatkan kegigihan dalam mengerjakan hal-hal yang sulit, memiliki luasan bidang prilaku yang baik dalam melakukan tugastugas yang rumit, serta memiliki ketekunan dalam mengerjakan tugas yang rumit.

\section{Saran}

Berdasarkan hasil penelitian, maka ada beberapa rekomendasi yang dapat dipertimbangkan dan menjadi bahan masukan untuk pihak-pihak yang berkepentingan dengan hasil atau temuan dari penelitian ini. Beberapa saran tersebut adalah:

1. Bagi Peneliti hendaknya memperhatikan variabel lain yang dapat mempengaruhi kemampuan berpikir tingkat tinggi siswa lainnya.

2. Bagi guru dan pihak sekolah, lebih memperhatikan sisi afektif siswa khususnya pada efikasi diri agar mampu menghasilkan siswa yang matang tidak hanya dalam kognitif tetapi juga dalam memotivasi dirinya sendiri yang nantinya juga akan membawa perkembangan yang signifikan terhadap tingkat kemampuan berpikir siswa tersebut.

3. Bagi siswa, dalam meningkatkan kemampuan berpikir khususnya dari kemampuan berpikir tingkat rendah kepada tingkat kemampuan berpikir tingkat tinggi, salah satunya dengan cara siswa lebih memperhatikan untuk meningkatkan tingkat kepercayaan dirinya sendiri terhadap kemampuan yang dimilikinya, karena hal tersebut atau yang disebut juga dengan efikasi diri jelas berkontribusi dalam meningkatkan perkembangan tingkat kemampuan berpikirnya.

\section{Daftar Pustaka}

Anderson, L. (2011). Kerangka Landasan Untuk Pembelajaran, Pengajaran, Dan Asesmen. Yogyakarta: Pustaka Pelajar.

Bandura, A. (1997). Self-Efficacy: Twoard a Unifying Theory of Behavioral Change. Psychological Review.

Bandura, A. (1986). Social Foundation of Thought and Action: A Social Cognitif Theory. Englewood Cliffs, NJ: Prentice Hall.

Barahal, S. L. (2008). Thinking About Thinking. Phi Delta Kappan.

Baron, R. A. (1991). Sosial Psychology: Understanding Human Interaction. USA: Ally \& BAcon.

Brookhart, S. M. (2010). How to Assess Higher-Order Thinking Skills in Your Classroom. Los Angeles: Alexandria.

Hoffman, B. G. (2009). The Influence of Selfefficacy and Working Memory Capacityon Problem-Solving. Learning and Induvidual Diferences.

Luthans, F. (2005). Organisation Behavior (10th ed) (terjemahan). The McGrawHill Companies, Inc.

Luthans, F. (2006). Perilaku Organisasi. Yogyakarta: Penerbit ANDI.

Murtinugraha, E. (2009). Gaya Belajar dan Index Of Learning Styles (ILS) Mahasiswa Pada Mata Kuliah MT 1 di Jurusan Teknik Sipil FT UNJ. Jakarta: 
Fakultas Teknik, Universitas Negeri Jakarta.

Myers, C. (2007). Teaching Critical Thinking. Tehran: Samt.

Nitko, A. J. (2007). Educational Assessment of Students (5th ed). Upper Saddle River, NJ: Pearson Education.

Setiyanto, I. (2014). Hubungan Antara Efikasi Diri Dengan Kematangan Karir Siswa Kelas XI SMK Negeri 8 Jakarta. Skripsi, Universitas Negeri Jakarta.

Tanta. (2013). Pengaruh Efikasi Diri, Kemandirian Belajar Dan Kebiasaan Berpikir Terbadap Hasil Belajar Biologi SMA Di Kota Jayapura Papua. Skripsi, Universitas Negeri Jakarta. 
Jurnal Pendidikan Teknik Sipil 